\title{
ALTERNATE USE OF DIFFERENT RICA PROBIOTIC BACTERIA ON SURVIVAL RATE AND PRODUCTION OF CULTURED TIGER SHRIMP IN SEMI-INTENSIVE PONDS
}

\author{
Muharijadi Atmomarsono" and Nurbaya \\ Research and Development Institute for Coastal Aquaculture, Maros
}

(Received 18 September 2014; Final revised 3 November 2014; Accepted: 10 November 2014)

\begin{abstract}
Tiger shrimp diseases have occured in Indonesian shrimp ponds for more than two decades. In order to overcome this problem, five types of the RICA probiotic bacteria were tested in nine $250 \mathrm{~m}^{2}$ semi-intensive ponds of the Research and Development Institute for Coastal Aquaculture Marana Station. In the present study three different alternate use of the RICA probiotics were tested for tiger shrimp culture incompletely randomized design experiment. There were three treatments here namely: $A$ ) alternate use of probiotic bacteria RICA-1, RICA-2, RICA-3; B) alternate use of probiotic bacteria RICA-4, RICA-5, RICA-3, and C) control (without probiotic bacteria); each treatment were applied in three replications. The results showed that survival rate and production of tiger shrimp in treatment $A(55.8 \%$ and $14.9 \mathrm{~kg} / \mathrm{pond})$ and $B(52.7 \%$ and $16.7 \mathrm{~kg} /$ pond) were significantly better $(\mathrm{P}<0.05)$ than those of in control ponds $(37.4 \%$ and $10.9 \mathrm{~kg} /$ pond). However, survival rate and production of tiger shrimp between treatment $A$ and $B$ were not significantly different $(P>0.05)$. The average total bacteria population in the cultured water media of treatment $A\left(4.32 \times 10^{4} \mathrm{cfu} / \mathrm{mL}\right)$ and $B(5.18$ $\left.\times 10^{4} \mathrm{cfu} / \mathrm{mL}\right)$ were relatively higher than control $\left(1.46 \times 10^{4} \mathrm{cfu} / \mathrm{mL}\right)$. However the percentage ratio of Vibrio spp. and total bacteria population in the cultured water media of treatment $A$ and $B$ were relatively lower than control. The lower survival rate and production of tiger shrimp in control (C) compared to probiotic treatments ( $A$ and $B$ ) were not just affected by the increase of Vibrio spp. ratio, but also affected by the increase of total organic matter and nitrite concentrations in the control ponds that were relatively higher than treatment $A$ and $B$.
\end{abstract}

KEYWORDS: RICA probiotic, alternate use, tiger shrimp, semi-intensive

\section{INTRODUCTION}

Shrimp diseases have caused high mortality in brackishwater shrimp aquaculture in Indonesia (Atmomarsono, 2004). Researchers have developed various approaches to improve shrimp survival, including using water reservoir and biofilter organisms for wastewater treatment (Atmomarsono et al., 1995; Muliani et al., 1998; Atmomarsono, 2004). The use of antibiotics to control Vibrio is not supported because of the development of resistant strains of Vibrio. An alternative approach is to use probiotic bacteria as an approach to reduce potential environmental impacts.

Probiotic bacteria are non-pathogenic bacteria that compete with pathogenic bacteria,

\# Corresponding author. Research and Development Institute for Coastal Aquaculture Jl. Makmur Dg. Sitakka No. 129, Maros 90512, Sulawesi Selatan, Indonesia. Phone: +62 411371544

E-mail: hari_atmo@yahoo.com 
demineralise organic matter and improve water quality (Poernomo, 2004). Probiotic bacteria can be isolated from the sea water and sea sediment, coral, pond sediment, mangrove leaves, and macroalgae (Haryanti et al., 2000; Muliani et al., 2003, 2004, 2006; Atmomarsono et al., 2009; Tampangallo et al., 2013).

Many species of bacteria have been proposed as probiotics, including: Bacillus sp., Bacillus subtilis, Lactobacillus spp., Brevibacillus sp., Pseudomonas sp., Pseudoalteromonas sp., Pseudomonas aeruginosa, Vibrio alginolyticus, and Vibrio carchariae. Probiotic bacteria have been used in hatcheries for the larval rearing of swimming crab Portunus trituberculatus and $P$. pelagicus (Nogami \& Maeda, 1992; Susanto et al., 2005), rainbow trout Oncorhynchus mykiss (Brunt \& Austin, 2005; Brunt et al., 2007), tiger shrimp Penaeus monodon (Meunpol et al., 2003) as well as for brine shrimp Artemia culture (Villamil et al., 2003).

The use of probiotics by farmers has had mixed success due to the use of different kinds of probiotics, their doses, and the method of application. The Research and Development Institute for Coastal Aquaculture (RICA), Maros, South Sulawesi, has developed several strains of probiotics bacteria which were isolated from brackishwater ponds, mangrove leaves, sea sediments, and macroalgae. RICA-1 is Brevibacillus laterosporus that is used to control total oganic matter and $\mathrm{H}_{2} \mathrm{~S}$ in shrimp culture water (Muliani et al., 2006; Atmomarsono et al., 2009). RICA-2 is Serratia marcescens that is used to control nitrite and nitrate in shrimp culture water (Muliani et al., 2004) and to enhance shrimp growth (Atmomarsono et al., 2009). RICA-3 is Pseudoalteromonas sp. Edeep1 that is used to decrease nitrite and control Vibrio spp. in shrimp culture water (Muliani et al., 2003, 2005; Atmomarsono \& Susianingsih, 2013). RICA-4 is Bacillus subtilis that has an effect similar to RICA-1. RICA-5 is Bacillus licheniformis that is used to control ammonia and nitrite in the pond water (Tampangallo et al., 2013).

Some laboratory-scale experiments had been undertaken to evaluate these five RICA probiotics, including the effects of different probiotics and application of the dose rates (Muliani et al., 2007), the composition of the probiotics (Nurbaya et al., 2007; Muliani et al., 2008a; Atmomarsono et al., 2009), and ratio of probiotic (Muliani et al., 2008b). Other aspects that are important are when and how to apply this probiotic bacteria to get better survival rate and production of shrimp (Atmomarsono \& Susianingsih, 2013). In this study we tested these five RICA probiotics to evaluate their effect on tiger shrimp survival and production in semi-intensive brackishwater culture ponds.

\section{MATERIALS AND METHODS}

This study was carried out at the Marana Experimental Ponds of the RICA, Maros, South Sulawesi, using nine $250 \mathrm{~m}^{2}$ ponds aerated with "supercharge blower". Each pond was stocked with PL-12 black tiger shrimp fry (initial average body weight $3 \mathrm{mg}$ ) at an initial stocking density of 10 shrimps $/ \mathrm{m}^{2}$. Prior to stocking the PLs were tested using PCR (IQ2000 test kit) to ensure that they were negative WSSV. The experimental design used was completely randomized design (CRD) with three treatments in three replicates. Three treatments tested here were: $(A)$ alternate use of probiotic bacteria RICA-1, RICA-2, and RICA-3; (B) alternate use of probiotic bacteria RICA-4, RICA-5, and RICA-3; and (C) control (without probiotic bacteria). The tiger shrimp were fed with a commercial pellet diet, containing 37\%-38\% crude protein and $4 \%$ $4.5 \%$ fat, from $100 \%$ of total biomass per day (given twice a day) at the beginning of the trial, decreasing to $2 \%$ of total biomass/day (given four times/day) at the end of the culture pe$\operatorname{riod}(13$ weeks).

Before being added to the ponds, probiotic bacteria $(200 \mathrm{~mL})$ were cultured using $1 \mathrm{~kg}$ of rice bran, $400 \mathrm{~g}$ of fish meal, $500 \mathrm{~g}$ of molasses, and $100 \mathrm{~g}$ of yeast in $20 \mathrm{~L}$ of brackishwater pond water (Poernomo, 2004). Probiotic bacteria cultures were applied twice each week at about $10 \mathrm{mg} / \mathrm{L}$ of 3-day fermented culture of bacteria. Alternating use of probiotic bacteria for treatment $A$ and $B$ was done every two weeks until harvest.

Survival rate and production of the tiger shrimp were measured after 13 weeks. Data were then analyzed using analysis of variance (ANOVA) followed by Least Significant Difference analysis (Steel \& Torrie, 1981).

Total bacterial count (TPC) in the pond water was analyzed using tryptic soy agar (TSA) media, while total Vibrio count (TBV) was analized using thiosulphate citrate bile-salt sucrose agar (TCBSA) media every other week (Austin, 1987; Buller, 2004). Data were then analysed graphically and discussed descriptively. 
Water quality variables of the shrimp pond water were monitored and measured in every two weeks. Total organic matter (TOM) and total alkalinity were measured titrimetically, while nitrite-nitrogen $\left(\mathrm{NO}_{2}-\mathrm{N}\right)$ and nitrate-nitrogen $\left(\mathrm{NO}_{3}-\mathrm{N}\right)$ were measured using spectrophotometer (Boyd, 1990; American Public Health Association, 1995). Water temperature and dissolved oxygen (DO) were monitored using DOmeter YSI model. Water $\mathrm{pH}$ was checked with $\mathrm{pH}$-meter, while salinity was checked with Atago hand refractometer. Data were then analysed graphically and discussed descriptively.

\section{RESULTS AND DISCUSSIONS}

\section{Population of Bacteria}

Total Bacteria and Total Vibrio spp. in the Pond Water

Figure 1 shows the change in total bacteria and total Vibrio spp. count (in logarithmic values) in the pond water during the experiment. For all treatments, total bacteria in the pond water tended to decrease for the fourth week to the sixth week, but increased again for the eighth week and the twelfth week of culture period. Total bacteria counts in the shrimp culture pond water in treatment $A(5,8 x$ $10^{3} \mathrm{cfu} / \mathrm{mL}$ to $1.45 \times 10^{5} \mathrm{cfu} / \mathrm{mL}$ with $4.32 \times$ $10^{4} \mathrm{cfu} / \mathrm{mL}$ in average $)$ and treatment $\mathrm{B}(8.8 \mathrm{x}$ $10^{3} \mathrm{cfu} / \mathrm{mL}$ to $1.2 \times 10^{5} \mathrm{cfu} / \mathrm{mL}$ with $5.18 \times 10^{4}$ $\mathrm{cfu} / \mathrm{mL}$ in average) were relatively higher than that of in treatment $\mathrm{C}\left(4.2 \times 10^{3} \mathrm{cfu} / \mathrm{mL}\right.$ to 3.19 $\times 10^{4} \mathrm{cfu} / \mathrm{mL}$ with $1.46 \times 10^{4} \mathrm{cfu} / \mathrm{mL}$ in average). However, there were no significantly difference $(P>0.05)$ among the three treatments tested here. Descriptively, this shows that the
RICA probiotic bacteria grows in the shrimp pond water, so that the number of total bacteria in treatment $A$ and $B$ were slightly higher than that of in treatment $C$. Similar research reported by Susianingsih et al. (2012a), with the use of probiotic bacteria RICA-1 (1 ${ }^{\text {st }}$ month), RICA-2 ( $2^{\text {nd }}$ month), RICA-3 ( $3^{\text {rd }}$ month), and RICA1 ( $4^{\text {th }}$ month) that total bacteria in the pond water tended to decrease from $10^{8} \mathrm{cfu} / \mathrm{mL}$ at the beginning to $10^{5} \mathrm{cfu} / \mathrm{mL}$ by the end of experiment. The continous growth of probiotic bacteria in the pond waters will improve water quality variables like decreasing total organic matter, ammonia, and nitrite that finally increase the survival rate and production of the shrimp (Table 3).

The numbers of total Vibrio spp. (TBV) from the beginning of the experiment to the sixth week were relatively constant for all three treatments, but increased to $3.45 \times 10^{3} \mathrm{cfu} /$ $\mathrm{mL}$ in the eight week in treatment $\mathrm{B}$ and decreased again to less than $1.0 \times 10^{3} \mathrm{cfu} / \mathrm{mL}$ until the end of experiment. Eventhough Vibrio spp. in the pond water in treatments $A$ and $B$ were sometime relatively higher than in treatment $\mathrm{C}$, the numbers of Vibrio spp. were still less than $10^{4} \mathrm{cfu} / \mathrm{mL}$, so that this Vibrio numbers were still safe for shrimp growth. According to Defoirdt (2007), the number of total $\mathrm{Vi}$ brio spp. will be pathogenic to the cultured shrimp if over $10^{4} \mathrm{cfu} / \mathrm{mL}$.

However, it appears that the ratio of total Vibrio spp. compared to total bacteria in the shrimp pond water is more important than the Vibrio spp. number it self. Table 1 shows that the ratio of Vibrio to total bacteria tended to increase during the culture period. This ratio
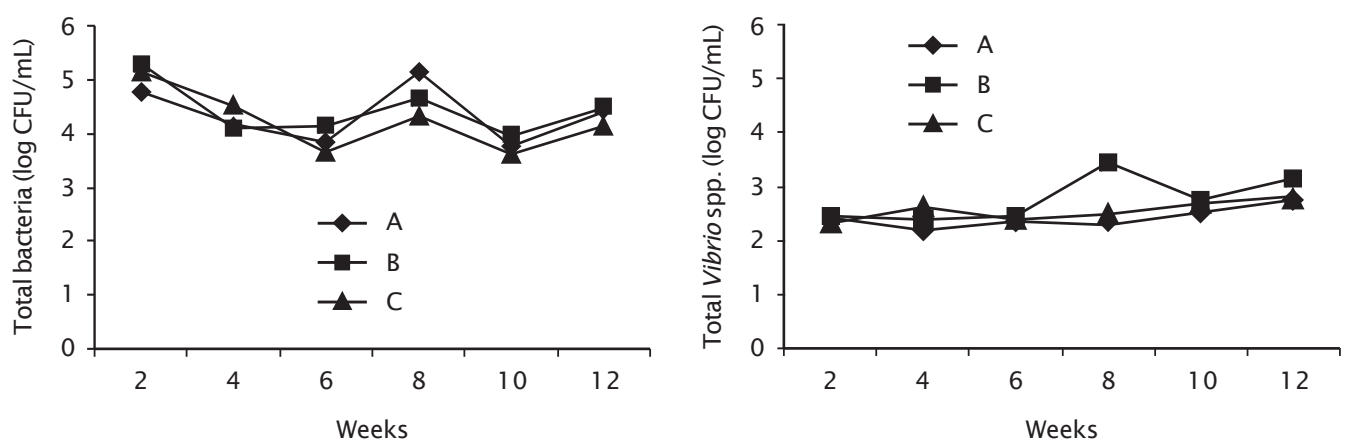

Figure 1. Total bacteria (TPC) and total Vibrio spp. (TBV) counts for three probiotic treatments in brackishwater ponds: A) alternate use of probiotic bacteria RICA-1, RICA-2, RICA-3; B) alternate use of probiotic bacteria RICA-4, RICA-5, RICA-3; C) control (without probiotic bacteria) 
Table 1. The ratio of Vibrio spp. number compared to total bacteria (\%) in the shrimp culture pond water

\begin{tabular}{ccccccc}
\hline \multirow{2}{*}{ Treat ment s } & \multicolumn{6}{c}{ Tiger shrimp cult ure period (weeks) } \\
\cline { 2 - 7 } & $\mathbf{2}$ & $\mathbf{4}$ & $\mathbf{6}$ & $\mathbf{8}$ & $\mathbf{1 0}$ & $\mathbf{1 2}$ \\
\hline A & 0.46 & 1.01 & 3.13 & 0.14 & 5.74 & 2.26 \\
B & 0.14 & 2.00 & 1.95 & 0.62 & 6.50 & 5.03 \\
C & 0.14 & 1.30 & 5.78 & 1.54 & 11.08 & 5.06 \\
\hline
\end{tabular}

Noted: $\mathrm{A}=$ Alternate use of probiotic bacteria RICA-1, RICA-2, RICA-3; B = Alternate use of probiotic bacteria RICA-4, RICA-5, RICA-3; C = Control (without probiotic bacteria)

in treatment $A(0.14 \%-5.74 \%)$ and B $(0.14 \%$ $6.50 \%)$ were relatively lower than in treatment C (0.14\%-1 1.08\%). This ratio might be correlated with the shrimp mortality in treatment C (control), especially when the Vibrio to total bacteria ratio increased over $10 \%$ as occured in the tenth week of this experiment. This ratio in treatment $C$ was $11.08 \%$, while in treatment $A$ it was only $5.74 \%$ and in treatment B was $6.50 \%$. The increase in the Vibrio ratio could be dangerous to the cultured shrimp especially when some water qualiy variables like total organic matter, ammonia-nitrogen, and nitrite-nitrogen were also getting worse. In this experiment, the increase of Vibrio ratio in treatment $\mathrm{C}$ over $10 \%$ along with relatively higher concentration of total organic matter $(73.4 \mathrm{mg} / \mathrm{L})$ and nitritenitrogen $(0.1328 \mathrm{mg} / \mathrm{L})$ may have increased the mortality of the cultured tiger shrimp.

The survival rate of cultured tiger shrimp in treatment $\mathrm{C}(37.4 \%)$ was significantly $(\mathrm{P}<0.05)$ lower than in treatment A (55.9\%) and B (52.7\%) (Table 3 ). This may have been caused by the

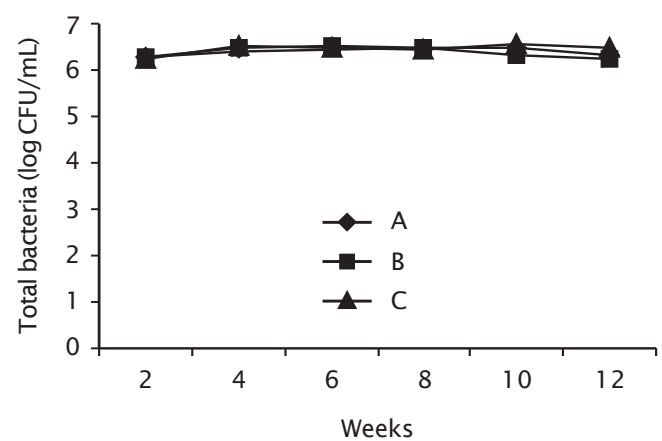

increase in the Vibrio ratio in the reared tiger shrimp pond water in control (C).

\section{Total Bacteria and Total Vibrio spp. in} the Pond Sediment

Total bacteria in the pond sediment were relatively stabile at about $10^{6} \mathrm{cfu} / \mathrm{g}$ from the beginning to the end of experiment (Figure 2). This shows that the application of alternate use of RICA probiotic bacteria did not affect to the number of total bacteria in the shrimp pond mud. Populations of total bacteriain the pond sediment during the experiment in all treatments were relatively similar to those reported by Susianingsih et al. (2012) i.e. $10^{6}-10^{7} \mathrm{cfu} / \mathrm{g}$, but they were lower than those reported by Garland (1983) in Buller (2004) which reached $10^{7}-10^{8} \mathrm{cfu} / \mathrm{g}$. The number of total bacteria and total Vibrio spp. in the pond sediment in this experiment are still in normal number for the cultured tiger shrimp, since they were lower than those reported by Garland (1983) in Buller (2004).

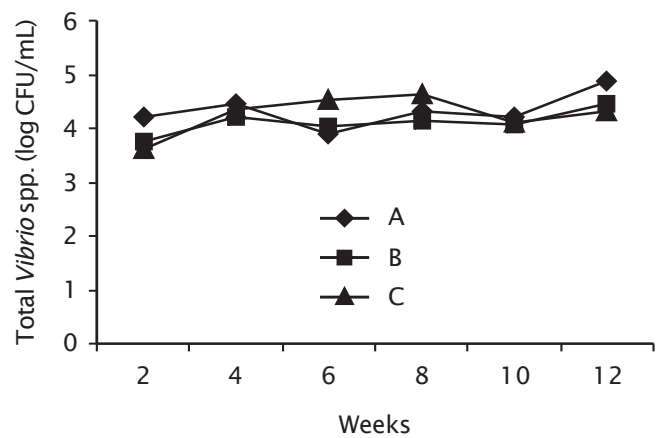

Figure 2. Total bacteria (TPC) and total Vibrio spp. (TBV) counts in pond sediments for three probiotic treatments in brackishwater ponds: A) alternate use of probiotic bacteria RICA-1, RICA-2, RICA-3; B) alternate use of probiotic bacteria RICA-4, RICA-5, RICA-3; C) control (without probiotic bacteria) 


\section{Water Quality}

\section{Total Organic Matter (TOM)}

In general, the concentration of total organic matter in the cultured shrimp pond water tended to increase from beginning of the experiment (33-37 mg/L) to the fourth week (56-64 mg/L) (Figure 3), but then remained relatively constant (54-64 mg/L) for the remainder of the experiment, except for the tenth week when TOM increased slightly to $70-73 \mathrm{mg} / \mathrm{L}$, before decreasing again to $65-68 \mathrm{mg} / \mathrm{L}$. The fluctuation of TOM in the pond waters for the three treatments were relatively similar, but the highest concentration $(73.4 \mathrm{mg} / \mathrm{L})$ of TOM occured in the control pond after ten weeks (Figure 3). This shows that the alternate use of the RICA probiotic bacteria (in treatments $A$ and B) had a positive effect in decreasing TOM in the cultured shrimp pond water. Susianingsih et al. (2012b) reported lower values of TOM $(15-40 \mathrm{mg} / \mathrm{L})$ than were recorded in this experiment. The higher concentration of TOM in the pond water during this experiment was possibly caused by different condition of the climate, that is dry season in this experiment, and rainy season in Susianingsih et al. (2012b) experiment.

\section{Nitrite-nitrogen $\left(\mathrm{NO}_{2}-\mathrm{N}\right)$}

Nitrite-nitrogen levels in pond water were relatively stable from the beginning to the fourth week of the experiment, but then increased sharply for the sixth week of culture in all three treatments (Figure 4). Highest levels were recorded in treatment $C$ (Control), followed by treatments $A$ and $B$ respectively (Figure 4). At the eighth week, concentration of nitrite-nitrogen slightly decreased until the end of experiment (twelfth to thirteenth week) (Figure 4). The increase in nitrite-nitrogen concentration by the end of the the sixth week showed that the nitrification process occured in the pond water due to the availability of nitrification bacteria like Nitrosomonas that change ammonia-nitrogen to nitrite-nitrogen. Then the second step of nitrification process, that is oxidation of nitrite-nitrogen to nitratenitrogenis carried out by nitrite oxidizing bacteria such as Nitrobacter (Ebeling et al., 2006). This second step was a relatively slower process especially in treatment $C$ (control), so that the concentration of nitrite-nitrogen in control pond water was relatively higher than in treatments $A$ and $B$. The contribution of Pseudoalteromonas sp. that has a role in controlling nitrite-nitrogen in treatments $A$ and $B$ showed a lower concentration of nitrite-nitrogen in these two treatments compared to that of the control. The role of decreasing nitritenitrogen was also carried out by the bacteria Bacillus licheniformis (RICA-5) in treatment B and bacteria Serratia marcescens (RICA-2) in treatment $A$. Both these bacteria could change ammonia-nitrogen to nitrite-nitrogen and finally to nitrate-nitrogen (Muliani et al., 2003, 2005; Atmomarsono \& Susianingsih, 2013; Tampangallo et al., 2013). Overall the concentrations of nitrite-nitrogen in this experiment

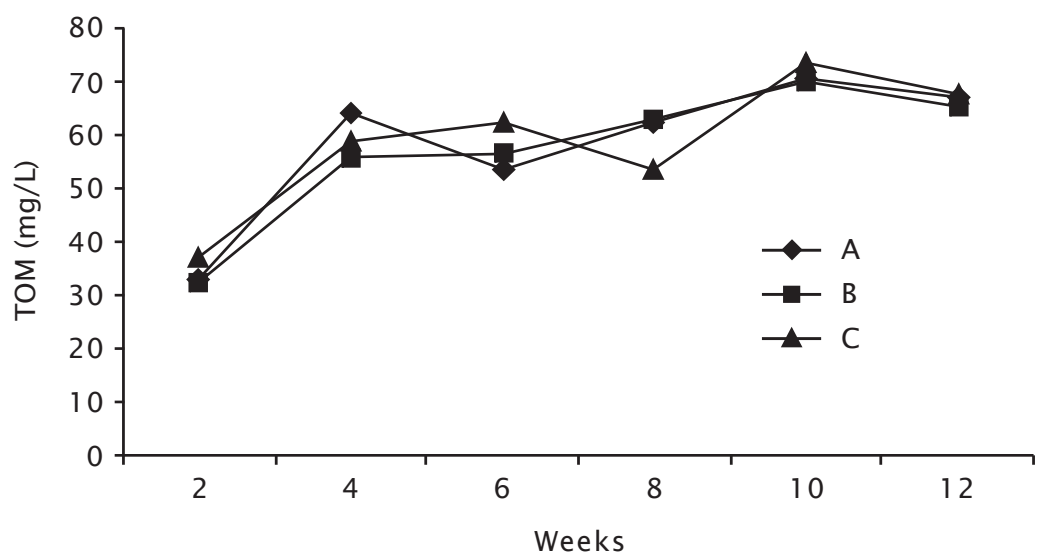

Figure 3. Total organic matter concentrations for three probiotic treatments in brackishwater ponds: A) alternate use of probiotic bacteria RICA-1, RICA-2, RICA-3; B) alternate use of probiotic bacteria RICA-4, RICA-5, RICA-3; C) control (without probiotic bacteria) 


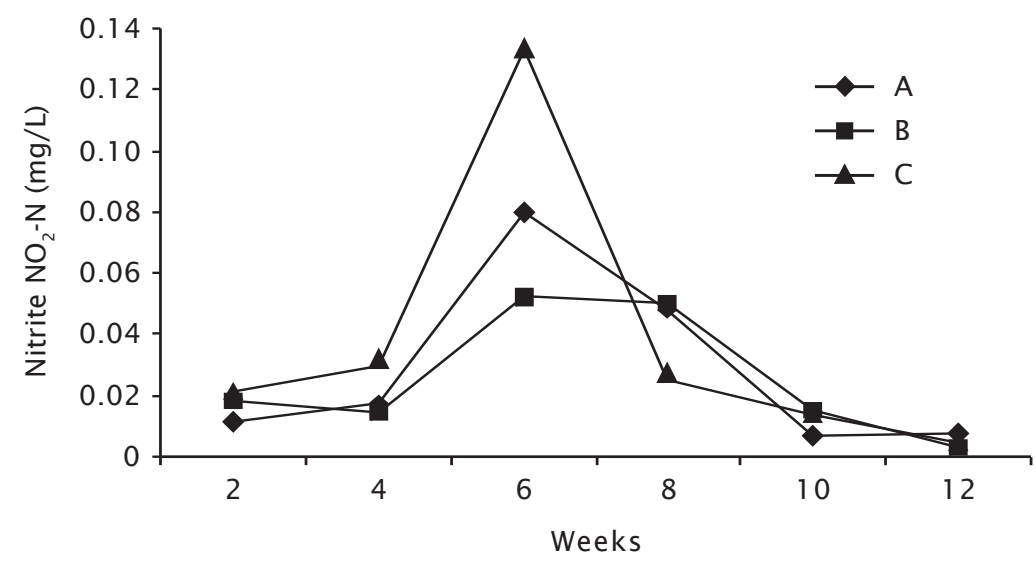

Figure 4. Nitrite-nitrogen concentration for three probiotic treatments in brackishwater ponds: A) alternate use of probiotic bacteria RICA-1, RICA-2, RICA-3; B) alternate use of probiotic bacteria RICA-4, RICA-5, RICA-3; C) control (without probiotic bacteria)

were safe for the growth of cultured tiger shrimp, because they were much lower than the level of $4 \mathrm{mg} / \mathrm{L}$ that is considered dangerous for cultured tiger shrimp (Boyd \& Fast, 1992).

\section{Nitrate-nitrogen $\left(\mathrm{NO}_{3}-\mathrm{N}\right)$}

Concentration of nitrate-nitrogen (Figure 5) tended to increase from the sixth week to the eighth week, except in treatment A which had relatively lower nitrate-nitrogen than the other two treatments in the eighth week. Concentration of nitrate-nitrogen during the tenth week had substantially decreased, but increased sharply at the twelfth week in treatments $A$ and $\mathrm{C}$ (Figure 5). It was reported by Susianingsih et al. (2012b), that the concentration of nitratenitrogen in the cultured shrimp pond water tended to decrease from the beginning to the end of experiment. Generally, the concentration of nitrate-nitrogen for the three treatments were not dangerous to the cultured shrimp, because nitrate-nitrogen is less toxic than ammonia-nitrogen and nitrite-nitrogen. However, to prevent from possible eutrophication in the cultured pond waters, the concentra-

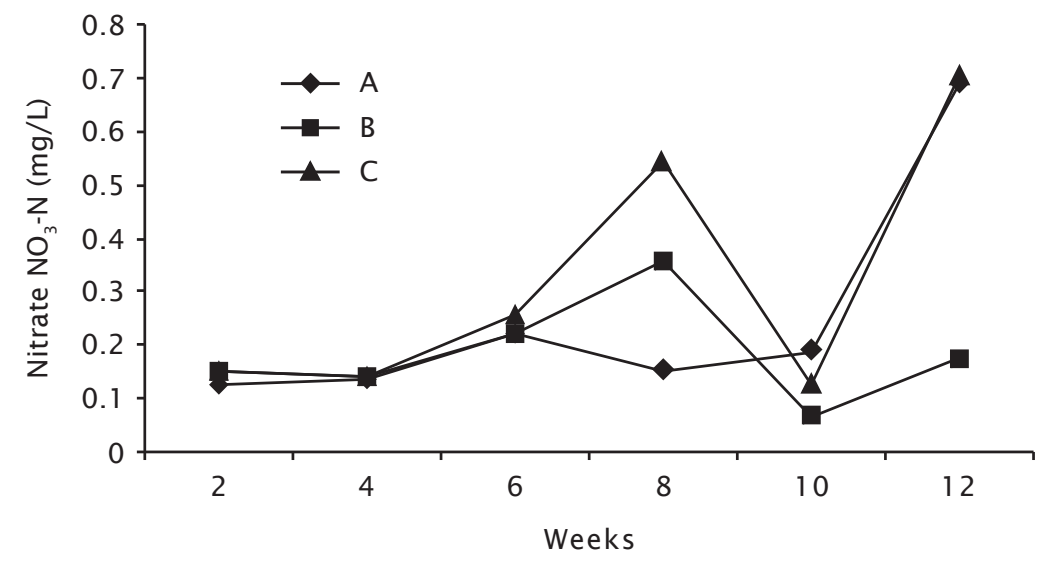

Figure 5. Nitrate-nitrogen concentration for three probiotic treatments in brackishwater ponds: A) alternate use of probiotic bacteria RICA-1, RICA-2, RICA-3; B) alternate use of probiotic bacteria RICA-4, RICA-5, RICA-3; C) control (without probiotic bacteria) 
tion of nitrate-nitrogen should not exceed 1 $\mathrm{mg} / \mathrm{L}$ (Wedemeyer, 1996).

\section{Other Water Quality Variables}

Concentration of total alkalinity, dissolved oxygen (DO), water temperature, and salinity in the cultured tiger shrimp pond waters were relatively the same for the three probiotic treatments (Table 2). Water $\mathrm{pH}$ in teatments $\mathrm{A}$ (7.28.7) and $B(7.2-8.6)$ were slightly lower than in treatment C (7.4-9.0) (Table 2). This might be caused by application of probiotic bacteria in treatments $A$ and $B$ which could maintain water $\mathrm{pH}$ more stabile than in control (C). According to Atmomarsono (2004), these water quality variables (Table 2 ) are still in good ranges for tiger shrimp culture.

\section{Performance of Cultured Tiger Shrimp}

Performance of tiger shrimp in this experiment was evaluated from the specific growth rate (SGR) of the shrimp, their survival rates, and their production. Table 3 shows that specific growth rates of shrimp in the three treatments were not significantly different $(P>0.05)$. This result shows that the environmental factors like available feed, pond water quality, and pond sediment quality might not affect directly to the shrimp growth. The average final weight of the cultured shrimp ranged between 11-13 g. This was smaller than reported by Susianingsih et al. (2012b) who achieved 44$53 \mathrm{~g}$ with the use of the same RICA probiotic bacteria, but with four months culture period, compared with three months for this study. This different result of the shrimp growth might be caused by different quality of the shrimp fry, different season, or the shorter culture period.

Survival rate and production of the cultured tiger shrimp in treatment $C$ (control) were significantly $(P<0.05)$ lower than in treatments $A$ and $B$ (Table 3). This suggests that the alternate use of the RICA probiotic bacteria either

Table 2. Ranges of water quality variables in the shrimp culture pond water

\begin{tabular}{lccc}
\hline \multirow{2}{*}{ Wat er quality variables } & \multicolumn{3}{c}{ Treat ment s } \\
\cline { 2 - 4 } & A & B & C \\
\hline Temperature $\left({ }^{\circ} \mathrm{C}\right)$ & $28.5-32.6$ & $28.4-32.5$ & $28.4-32.8$ \\
Salinity $(\mathrm{g} / \mathrm{L})$ & $18-35$ & $18-35$ & $18-35$ \\
Dissolved oxygen $(\mathrm{mg} / \mathrm{L})$ & $2.9-6.6$ & $2.8-6.9$ & $2.8-6.6$ \\
Total alkalinity $\left(\mathrm{mg} \mathrm{CaCO}{ }_{3}\right.$ equivalent/L) & $85.6-167.2$ & $83.6-150.5$ & $83.6-171.4$ \\
$\mathrm{pH}$ & $7.2-8.7$ & $7.2-8.6$ & $7.4-9.0$ \\
\hline
\end{tabular}

Noted: $\mathrm{A}=$ Alternate use of probiotic bacteria RICA-1, RICA-2, RICA-3; $\mathrm{B}=$ Alternate use of probiotic bacteria RICA-4, RICA-5, RICA-3; C = Control (without probiotic bacteria)

Table 3. Size, specific growth rate, survival rate, and production of tiger shrimp reared with three different probiotic treatments

\begin{tabular}{lccc}
\hline \multirow{2}{*}{ Variables } & \multicolumn{3}{c}{ Treatment s } \\
\cline { 2 - 4 } & A & B & C \\
\hline Initial weight (g) & 0.003 & 0.003 & 0.003 \\
Final weight (g) & $10.6 \pm 0.9^{\mathrm{a}}$ & $12.9 \pm 2.6^{\mathrm{a}}$ & $11.8 \pm 1.7^{\mathrm{a}}$ \\
Daily specific growth rate (\%/day) & $9.08 \pm 0.09^{\mathrm{a}}$ & $9.28 \pm 0.22^{\mathrm{a}}$ & $9.19 \pm 0.16^{\mathrm{a}}$ \\
Survival rate (\%) & $55.9 \pm 6.7^{\mathrm{a}}$ & $527 \pm 9.0^{\mathrm{a}}$ & $37.4 \pm 5.7^{\mathrm{b}}$ \\
Production $\left(\mathrm{kg} / 250 \mathrm{~m}^{2}\right)$ & $14.9 \pm 3.0^{\mathrm{a}}$ & $16.7 \pm 0.2^{\mathrm{a}}$ & $11.0 \pm 0.1^{\mathrm{b}}$ \\
Production $(\mathrm{kg} / \mathrm{ha})$ & $596 \pm 120^{\mathrm{a}}$ & $668 \pm 8^{\mathrm{a}}$ & $440 \pm 4^{\mathrm{b}}$ \\
\hline
\end{tabular}

Notes: Values followed by the same superscript in the same rows mean not significantly different $(\mathrm{P}>0.05)$ among treatments tested 
in treatment $A$ (RICA-1, RICA-2, and RICA-3) or in treatment B (RICA-4, RICA-5, and RICA-3) could protect the cultured tiger shrimp from the attack of pathogenic Vibrio spp. and other pathogenic organisms. In addition, the alternate use of the RICA probiotic bacteria (in treatment $\mathrm{A}$ or $\mathrm{B}$ ) tended to have better water quality especially in controlling total organic matter, nitrite-nitrogen, and $\mathrm{pH}$ in the cultured shrimp pond waters, which may also have contributed to better survival and production of tiger shrimp. However, the survival rates and prodution of tiger shrimp here were lower than those reported by Susianingsih et al. (2012a; 2012b).

\section{CONCLUSIONS}

Based on the above results and discussions, it is concluded that the alternate use of the RICA probiotic bacteria could reduce total oganic matter and nitrite-nitrogen, as well as the ratio of Vibrio spp. to total bacteria in the cultured shrimp pond water. The alternate use of the RICA probiotic bacteria in treatments $A$ and $B$ could protect the cultured shrimp from possible pathogenic Vibrio spp., increasing the survival rate and production of the shrimp.

\section{ACKNOWLEDGEMENTS}

Both authors would like to express their appreciation to the Director of the Research and Development Institute for Coastal Aquaculture (RICA) and the Director of the Center for Aquaculture Research and Development for their support in funding this experiment. Their special thanks are also expressed to all researchers of the RICA, especially to Dr. Ir. Usman, M.S. for his special help, and also to all of the tehnicians in the RICA office who helped for analysing bacteria, water quality variables, and other activities that make this useful experiment was smoothly done.

\section{REFERENCES}

American Public Health Association (APHA). (1995). Standard methods for examination of water and waste water. $19^{\text {th }}$ edition. American Public Health Association. Washington D.C., $1082 \mathrm{pp}$.

Atmomarsono, M. (2004). Pengelolaan kesehatan udang windu, Penaeus monodon di tambak. Aquacultura Indonesiana, 5(2), 73 78.

Atmomarsono, M., Muliani, \& Ismawati, S. (1995). Prospek penggunaan tandon pada budi- daya udang windu. Makalah disajikan pada "Ekspose Hasil Penelitian Di Instalasi Pengkajian Teknologi Pertanian Wonocolo". Surabaya.

Atmomarsono, M., Muliani, \& Nurbaya. (2009). Penggunaan bakteri probiotik dengan komposisi berbeda untuk perbaikan kualitas air dan sintasan pasca larva udang windu. J. Ris. Akuakultur, 4(1), 73-83.

Atmomarsono, M., \& Susianingsih, E. (2013). Tiger shrimp culture in South Sulawesi, Indonesia using local probiotic bacteria. p. 110-115. In Sudaryono, A., Hasan, M., \& Budi, G.P. (Eds.), Proceeding International Conference of Aquaculture Indonesia (ICAI) 2012. Indonesian Aquaculture Society, Semarang.

Austin, B. (1987). Marine microbiology. Cambridge University Press. Cambridge, 222 pp.

Boyd, C.E. (1990). Water quality in ponds for aquaculture. Birmingham Publishing Co. Birmingham, Alabama. USA, $482 \mathrm{pp}$.

Boyd, C.E., \& Fast, A.W. (1992). Pond monitoring and management. p. 497-514. In Fast, A.W. \& Lester, L.J. (Eds.), Marine Shrimp Culture: Principles and Practices. Elsevier Science Publications. Amsterdam.

Brunt, J., \& Austin, B. (2005). Use of a probiotic to control lactococcosis and steptococcosis in rainbow trout, Oncorhynchus mykss (Walbaum). Journal of Fish Diseases, 28, 693-701.

Brunt, J., Fyzul, A.N., \& Austin, B. ((2007). The development of probiotics for control of multiple bacteria diseases of rainbow trout, Oncorhynchus mykiss (Walbaum). Journal of Fish Diseases, 30, 573-579.

Buller, N.B. (2004). Bacteria from fish and other aquatic animals: A practical identification manual. CABI Publish. Wallingford, Oxfordshire. U.K., $361 \mathrm{pp}$.

Defoirdt, T. (2007). Quorum sensing disruption and the use of short-chain fatty acids and polyhydroxyalkanoates to control luminescent vibriosis. Ph.D. Thesis. Ghent University. Belgium, 204 pp.

Ebeling, J.M., Timmons, M.B., \& Bisogni, J.J. (2006). Engineering analysis of the stoichiometry of photoautotrophic, autotrophic and heterotrophic removal of ammonia-nitrogen in aquaculture systems. Aquaculture, 257, 346-358.

Haryanti, Sugama, K., Tsumura, S., \& Nishijima, T. (2000). Vibriostatic bacterium isolated 
from seawater: Potentiality as probiotic agent in the rearing of Penaeus monodon larvae. Indonesian Fisheries Res. Journal, 6, 26-32.

Meunpol, O., Lopinyosiri, K., \& Menasveta, P. (2003). The effects of ozone and probiotics on the survival of black tiger shrimp (Penaeus monodon). Aquaculture, 220, 437448.

Muliani, Atmomarsono, M., \& Madeali, M.I. (1998). Pengaruh penggunaan kekerangan sebagai biofilter terhadap kelimpahan dan komposisi jenis bakteri pada budidaya udang windu (Penaeus monodon) dengan sistem resirkulasi air. J. Pen. Perik. Indonesia, 3, 54-61.

Muliani, Nurbaya, \& Atmomarsono, M. (2006). Penapisan bakteri yang diisolasi dari tambak udang sebagai kandidat probiotik pada budidaya udang windu, Penaeus monodon. J. Ris. Akuakultur, 1(1), 73-85.

Muliani, Nurbaya, \& Madeali, M.I. (2008a). Total bakteri, Vibrio spp., Sulfat Reduction Bacteria (SRB), dan Sulfur Oxidazing Bacteria (SOB) dalam wadah pemeliharaan udang windu dengan pemberian bakteri probiotik sistem bergilir. p. 134-139. In Litaay, M., Fachruddin, Sukendarsi, E., \& Zulkifli, A. (Eds.), Prosiding Seminar Nasional Biologi XIX. Makassar, 9-10 Juli 2008.

Muliani, Nurbaya, \& Tampangallo, B.R. (2008b). Pengaruh rasio bakteri probiotik terhadap perubahan kualitas air dan sintasan udang windu, Penaeus monodon dalam akuarium. J. Ris. Akuakultur, 3(1), 33-42.

Muliani, Nurbaya, \& Tompo, A. (2005). Pengaruh jenis dan konsentrasi bakteri probiotik terhadap kualitas air dan sintasan pascalarva udang windu yang dipapar dengan White Spot Syndrome Virus (WSSV). Makalah dipresentasikan pada Seminar Nasional dan Kongres Biologi XIII. Yogyakarta, 1617 September 2005, 10 pp.

Muliani, Nurbaya, Tompo, A., \& Atmomarsono, M. (2004). Eksplorasi bakteri filoster dari tanaman mangrove sebagai bakteri probiotik pada budidaya udang windu, Penaeus monodon. J. Pen. Perik. Indonesia, 2, 47-57.

Muliani, Susianingsih, E., \& Nurbaya. (2007). Perubahan kualitas air dan sintasan udang windu (Penaeus monodon) dalam laboratorium yang ditritmen dengan bakteri probiotik dengan komposisi jenis dan kepadatan yang berbeda. p. 286-294. In Akhmad, T., Haryanti, Giri, N.A., Sumiarsa,
G., Rachmansyah, \& Insan, I. (Eds.), Pengembangan Teknologi Budidaya Perikanan. Balai Besar Riset Perikanan Budidaya Laut. Badan Riset Kelautan dan Perikanan.

Muliani, Suwanto, A., \& Hala, Y. (2003). Isolasi dan karakterisasi bakteri asal laut Sulawesi untuk biokontrol penyakit vibriosis pada larva udang windu (Penaeus monodon Fab.). Hayati, 10, 6-11.

Nogami, K., \& Maeda, M. (1992). Bacteria as biocontrol agents for rearing larvae of the crab Portunus triberculatus. J. Fish. Aquat. Sci., 49, 2373-2376.

Nurbaya, Nurhidayah, Muliani, \& Madeali, M.I. (2007). Pengaruh perbedaan komposisi bakteri probiotik terhadap kualitas air dan sintasan udang windu (Penaeus monodon). In Purnomo, Fajar, M., Yaniharto, D., Febriani, M., \& Sudaryono, A. (Eds.), Prosiding Seminar Aquaculture Indonesia 2007. Surabaya, p. 62-67.

Poernomo, A. (2004). Technology of probiotics to solve the problems in shrimp pond culture and the culture environment. Paper presented in "The National Symposium on Development and Scientific and Technology Innovation in Aquaculture", January, 27 29, 2004. Patrajasa Hotel. Semarang, 25 pp.

Susianingsih, E., Nurbaya, \& Atmomarsono, M. (2012a). Pengaruh kombinasi jenis bakteri probiotik berbeda terhadap sintasan dan produksi udang windu di tambak semiintensif. J. Ris. Akuakultur, 7(8), 489-502.

Susianingsih, E., Nurbaya, \& Atmomarsono, M. (2012b). Sintasan dan produksi udang windu di tambak pada aplikasi bakteri probiotik berbeda. p. RB-13, 1-7. In Isnansetyo, A., Husni, A., Djumanto, Rachmawati, N., Widaningroem, R., Rustadi, Suadi, \& Ustadi (Eds.), Prosiding Seminar Nasional Tahunan IX Hasil Penelitian Perikanan dan Kelautan Tahun 2012. Jurusan Perikanan Fakultas Pertanian, UGM, Yogyakarta.

Steel, R.G.D., \& Torrie, J.H. (1981). Principles and procedures of statistics. A biometrical Approach ( $2^{\text {nd }}$ edition). International Student Edition. McGraw-Hill International Book Company, 633 pp.

Susanto, B., Setyadi, I., Syahidah, D., Marzuqi, M., \& Rusdi, I. (2005). Penggunaan bakteri probiotik sebagai kontrol biologi dalam produksi massal benih rajungan (Portunus pelagicus). J. Penel. Perik. Indonesia, 11, 15 23.

Tampangallo, B.R., Atmomarsono, M., \& Muliani. 
(2013). Isolasi dan identifikasi bakteri penghasil enzim amilase, protease, kitin, dan selulose dari makroalga. Prosiding Forum Inovasi Teknologi Akuakultur. Pusat Penelitian dan Pengembangan Perikanan Budidaya. Jakarta, p. 825-832.
Villamil, I., Firgueras, A., Planas, M., \& Novon, B. (2003). Control of Vibrio alginolyticus in artemia culture by treatment with bacterial probiotics. Aquaculture, 219, 43-56.

Wedemeyer, G.A. (1996). Physiology of Fish in Intensive Culture Systems. Chapman \& Hall. New York, 277 pp. 